\title{
Expression of p-53 and Cox-2 Genes as Tumour Markers in Spontaneous Canine Mammary Tumours
}

\author{
Kodakkadan Manikkan Dileepkumar ${ }^{1}$, Swapan Kumar Maiti ${ }^{2 *}$, Kumar Naveen ${ }^{2}$, Ajantha \\ Ravindran Ninu ${ }^{3}$, Abhijit Mitra ${ }^{2}$
}

${ }^{1}$ Department of Veterinary Surgery $\&$ Radiology, College of Veterinary and Animal Sciences, Mannuthy, Thrissur- 680 651, Kerala, India; ${ }^{2}$ Surgery Division, Indian Veterinary Research Institute, Izatnagar- 243 122, Uttar-Pradesh, India; ${ }^{3}$ Department of Veterinary Surgery $\Xi^{2}$ Radiology, Veterinary College ${ }^{\circ}$ Research Institute, Tirunelveli, TANUVAS, Tamil Nadu, 627358, India.

Abstract | Mammary neoplasms are the most frequently observed neoplasms in female dogs and constitute an important problem in veterinary medicine. The objective of this study was to investigate the p 53 and Cox- 2 gene expressions profile in mammary tumours of dogs of different histological types in comparison to healthy mammary tissues using quantitative real time PCR (qPCR) assay. A total of 12 cases ( 5 benign lesions: adenomas and benign mixed tumour and 7 malignant lesions: carcinomas and malign mixed tumour) were examined. Higher expression levels for p53 and Cox-2 genes in mammary tumour tissues were observed as compared to normal mammary tissues. Expression of both genes was relatively higher in malignant tumour than benign. These results show that p53 and Cox-2 genes may be useful tumour markers for early evaluating malignancy in canine mammary tumours.

Keywords | Dog, mammary tumours, p53, Cox-2, tumour markers

Editor | Kuldeep Dhama, Indian Veterinary Research Institute, Uttar Pradesh, India.

Received | May 17, 2016; Accepted | May 29, 2016; Published | June 16, 2016

*Correspondence | Dr Swapan Kumar Maiti, Principal Scientist, Surgery Division, Indian Veterinary Research Institute, Izatnagar-243 122, Uttar-Pradesh, India;

Email: swapanivri@gmail.com, maiti_62@rediffmail.com

Citation | Dileepkumar KM, Maiti SK, Naveen K, Ninu AR, Mitra A (2016). Expression of p-53 and Cox-2 genes as tumour markers in spontaneous canine mammary tumours. Adv. Anim. Vet. Sci. 4(6): 294-300.

DOI | Http://dx.doi.org/10.14737/journal.aavs/2016/4.6.294.300

ISSN (Online) | 2307-8316; ISSN (Print) | 2309-3331

Copyright (c) 2016 Dileepkumar et al. This is an open access article distributed under the Creative Commons Attribution License, which permits unrestricted use, distribution, and reproduction in any medium, provided the original work is properly cited.

\section{INTRODUCTION}

$I^{\prime}$ female dogs, mammary glands are frequent locations for the development of tumours and form second most common neoplasia (Maiti, 2006; Maiti et al., 2009; Khimta et al., 2010; Maiti et al., 2011; Dileepkumar et al., 2015). Activated genes present in different tumours are not normally expressed in the tissue from which they originate. The "tumour markers" are the proteins derived from the expression of these genes. For diagnosis and assessing the evolution of the tumours, detection and quantification of these proteins or tumour markers are so essential.

The $\mathrm{p} 53$ gene mutations and protein overexpression are useful predictors of increased malignant potential and poor prognosis in canine mammary tumours (Lee et al., 2004). The p53 is a significant prognostic marker for survival in early breast cancer in human (Linjawi et al., 2004). The p53 is the most commonly mutated gene in human cancers and is found to be altered in dog cancers. In canine mammary tumours, the $\mathrm{p} 53$ gene may be useful marker for evaluating malignancy (Ilhan et al., 2008). However, the wild type $\mathrm{p} 53$ in normal cells is undetectable by immunohistochemistry because of its short life (Misdrop et al., 1999). Cox-2 plays an important role in mammary tumour initiation and progression in human patients (Soslow et al., 2000; Queiroga et al., 2007). There is a strong positive correlation between expression of Cox-2 and grade of malignancy in the tumours. In canine mammary tumours, increased micro vessel density and increased Cox- 2 expression were linearly related to worse prognosis and shorter overall survival (Queiroga et al., 2007). Expression of Cox2 and p 53 genes in canine mammary tumours are reported but all those based on immunohistochemistry (Brunelle et al., 2006; Queiroga et al., 2007; Ilhan et al., 2008), however, there are scanty of reports based on PCR technology. 

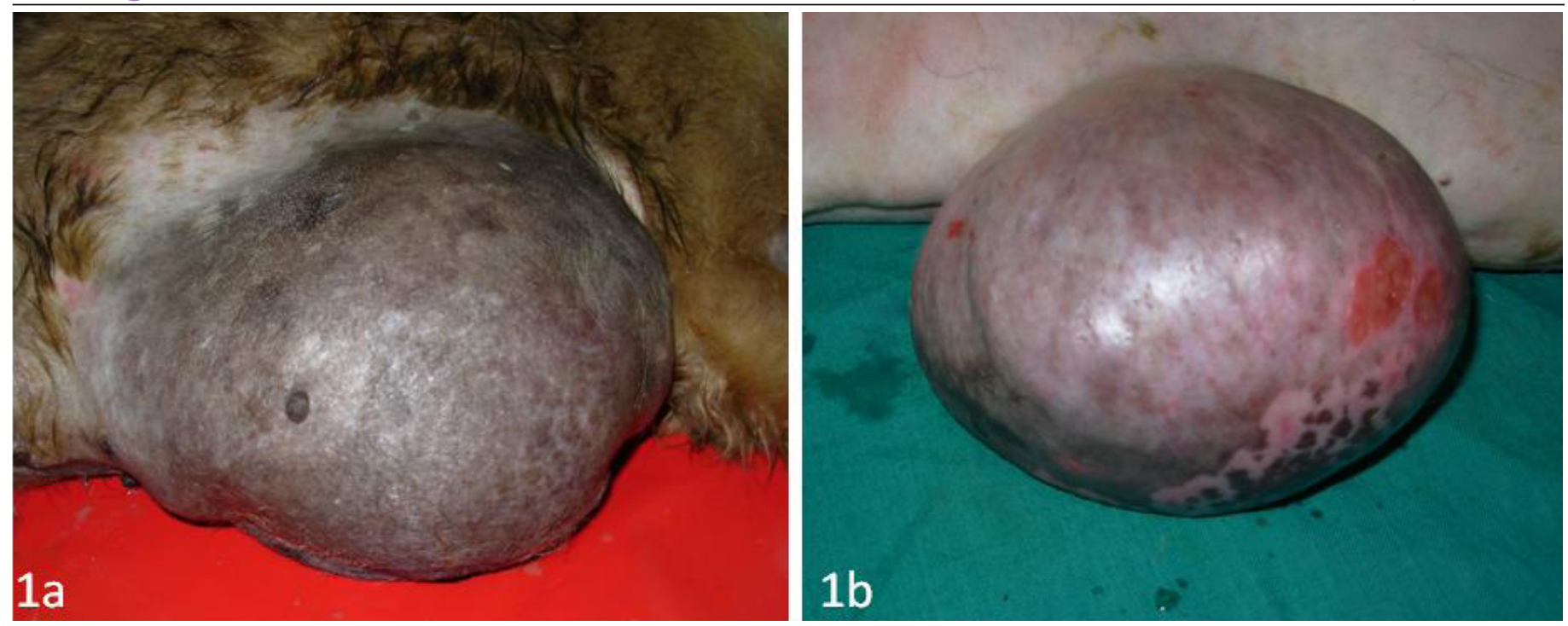

Figure 1: Mammary tumour in a female dog

Human and canine mammary tumours are frequently similar to their biological properties and histological origin and many researchers suggest that canine mammary tumours may serve as good models for human breast tumours (I1han et al., 2008). The present study is therefore, designed to investigate the efficiency and expression of $\mathrm{p} 53$ and Cox-2 genes as tumour markers in different histological types of canine mammary tumours through RTqPCR technology.

\section{MATERIALS AND METHODS}

A total of 12 canine mammary tumours were collected during surgery or biopsy in the Institute Referral Veterinary Polyclinics (Figure $1 \mathrm{~A}$ and $1 \mathrm{~B}$ ). Clinical staging of the canine mammary tumours was done as per previous report (Owen, 1980). Samples of 12 normal mammary tissues were obtained from 12 clinically healthy dogs without any tumours.

Tissue samples were first fixed in 10\% formalin, and then it was stained with Haematoxylin and Eosin (H\&E) for histopathological examination. Diagnosis of mammary tumours was made by two independent pathologists according to WHO classification system of canine mammary tumours (Misdrop et al., 1999).

Tumour mass was collected by biopsy/surgery. The total RNA was isolated from mammary tumours using Tri-Reagent following the manufacturer's instructions (Sigma, USA). The first strand cDNA was synthesized using iScript Select cDNA Synthesis Kit (BIORAD).

A total of 12 tumour samples and 12 normal mammary tissue samples were used in this study. Each DNase treated total RNA sample $(1 \mu \mathrm{g})$ was reverse transcribed with suitable negative and positive controls using the iScript DNA synthesis kit according to the manufacturer's instructions

(BIORAD). Negative controls were run that contained all the components except reverse transcriptase. Real-Time PCR (Mode 7500) was used for quantification of the expression of mRNA of the candidate genes. Primer Express 3.0 software was used for designing gene specific primers for the genes on the basis of respective cDNA sequence given below in Table 1 .

Table 1: List of primers used in Real Time PCR

$\begin{array}{ll}\text { Genes } & \text { Primer sequences } \\ \text { p53 } & \text { F :5'-GCGGCCCATCCTCACTATC-3' } \\ & \text { R:5'-CACAAACGCGTACCTCAAAGC-3' } \\ \text { Cox-2 } & \text { F :5'-ATGGGTGTGAAAGGCAAGAAA-3' } \\ & \text { R:5'-GGTAAAGTGCTGGGCAAAGAAT-3' } \\ \text { RPL } & \text { F:5'-ACCAGTCAGACCGATATGTCAAAA-3' } \\ & \text { R:5'-TTGTCAATGCCTCTGGGTTTC-3' }\end{array}$

Table 2: Cycling conditions for RT-qPCR

\begin{tabular}{|llll}
\multicolumn{3}{l}{ Thermocycling Condition } \\
Stage & Repetition & Temperature & Time \\
\hline 1 & 1 Cycle & $50^{\circ} \mathrm{C}$ & $2 \mathrm{~min}$ \\
\hline 2 & 1 Cycle & $95^{\circ} \mathrm{C}$ & $10 \mathrm{~min}$ \\
\hline 3 & 40 Cycle & $95^{\circ} \mathrm{C}$ & $15 \mathrm{sec}$ \\
\hline 4 & 40 Cycle & $60^{\circ} \mathrm{C}$ & $1 \mathrm{~min}$ \\
\hline $\begin{array}{l}\text { Denaturing condition } \\
1\end{array}$ & 1 cycle & $95^{\circ} \mathrm{C}$ & $15 \mathrm{sec}$ \\
\hline & $60^{\circ} \mathrm{C}$ & $20 \mathrm{sec}$ \\
\hline & $95^{\circ} \mathrm{C}$ & $15 \mathrm{sec}$ \\
\hline
\end{tabular}

For the analysis of data, Ribosomal protein (RPL) was used as a house-keeping gene. In all samples, PCR reactions were performed in triplicate. PCR amplification was done in $20 \mu 1$ volume reaction containing $1 X$ SYBR Green PCR master mix, 5 pmols of each gene-specific primer and 
$4.0 \mu \mathrm{l}$ of cDNA template were used. PCR cycling conditions were carried out as described in the Table 2. For the real time PCR assay, negative and positive controls were included. The cDNA was not added in the negative control (NTC). For determination of the efficiency of the selected primer pairs, calculation was done as follows: a serial dilution of the template was run with each primer pair, plotted the $\log$ of the dilution against the $\mathrm{Ct}$ value of each dilution. To calculate the efficiency of the PCR reaction, the slope of the resulting regression equation was used using $\mathrm{E}=-1+10^{(-1 / \text { slope })}$ equation. A dissociation curve was generated after completion of amplification for each sample and analyzed in comparison to negative and positive controls, to determine the specificity of PCR reaction. Relative Quantification (RQ) using the comparative CT method was used for calculation of mRNA expression of candidate genes (Livak and Schmittgen, 2011).

The comparative critical threshold (CT) value was utilized for evaluation of relative quantification of gene expression. The $\Delta \mathrm{CT}$ value was calculated by subtracting $\mathrm{CT}$ values for each mature mRNA reaction from the respective CT values of the RPL control (i.e. Ct target gene - Ct endogenous control $=\Delta \mathrm{Ct}$, Normalization to endogenous control). Normalization to calibrator sample was done by calculating $\Delta \Delta \mathrm{Ct}(\Delta \mathrm{Ct}$ sample $-\Delta \mathrm{Ct}$ calibrator $=\Delta \Delta \mathrm{Ct})$. Relative quantitative $(\mathrm{RQ})=2^{-\Delta \Delta \mathrm{Ct}}$ and the graphical representation was made based on these data.

All the data were analyzed by analysis of variance (ANOVA) as per standard statistical methods, using SPSS software package (version 16). The various scores were compared with Kruskal-Wallis test.

Necessary permission was undertaken from the Institute Animal Ethics Committee (IAEC) to conduct this research work in clinical cases.

\section{RESULTS}

Canine mammary neoplasm cases were presented as circumscribed nodules with variable size. The 12 cases were recorded in the age group of 7-15 years. Out of 12 mammary tumours, five cases had multiple growths and seven cases had solitary growth. Ulcerated and infected were in four cases whereas eight cases were non-infected. Clinical staging of the 12 canine mammary tumours were recorded; 6 cases $(50 \%)$ were in clinical stage IV, followed by 4 cases (33.33\%) were in stage III and 1 case (8.33\%) each in stage II and stage V.

The detailed histopathological findings in canine mammary tissues (normal and tumours) were shown in Table 3. Among the 12 mammary tumours investigated, 5 were considered as benign lesions and were essentially adeno- mas and benign mixed tumour. Carcinomas were the most frequent malignant tumours whereas malign mixed tumour also identified. The main types of carcinomas found in the present study were solid carcinomas and papillary adenocarcinoma (Figure 2A and 2B).
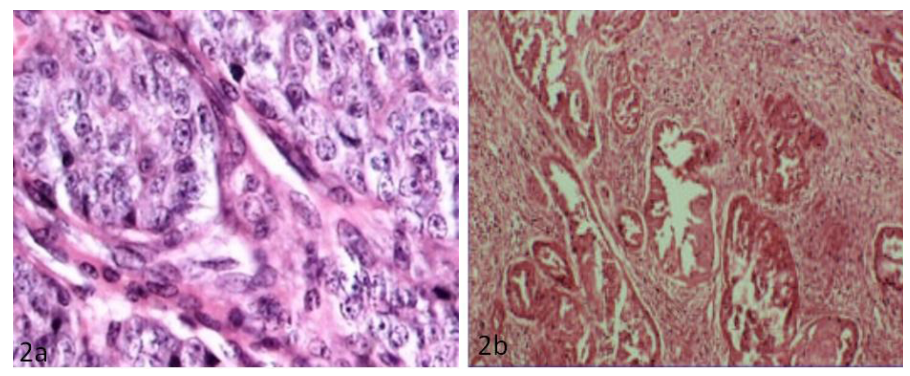

Figure 2: a) Solid carcinoma characterized by pleomorphic cells with vesicular nucleus (H\&E x40); b) Papillary adenocarcinoma characterized by pockets of proliferative cells invading the parenchyma in papillary pattern with numerous mitotic figures (H\&E x10)

Table 3: Histological type of mammary tumours

$\begin{array}{lc}\text { Histological diagnosis } & \text { No of samples } \\ \text { (1) Normal mammary gland } & 12 \\ \text { (2) Benign tumours } & \\ \text { - Simple adenoma } & 02 \\ \text { - Complex adenoma } & 01 \\ \text { - Papillary adenoma } & 01 \\ \text { - Benign mixed tumour } & 01 \\ \text { (3) Malignant tumours } & \\ \text { - Solid carcinoma } & 02 \\ \text { - Papillary adenocarcinoma } & 02 \\ \text { - Squamous cell carcinoma } & 01 \\ \text { - Fibrosarcoma } & 01 \\ \text { - Mixed tumour carcinoma } & 01\end{array}$

RNA samples that showed a smear with three higher intensity ribosomal RNA bands of about 28s, 18 s and 5.8 s RNA on $1 \%$ agarose gel electrophoresis were processed (Figure 3).

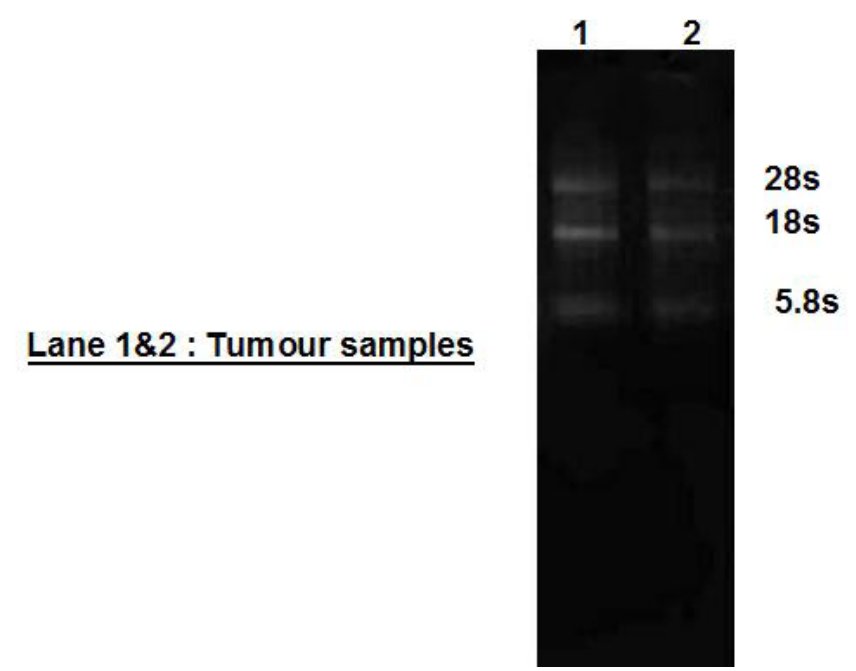

Figure 3: Quality and integrity of total RNase isolated from canine mammary tumour 
OPEN OACCESS

RNA samples with OD260/OD280 ranged at 1.96-2.02, indicating high quality RNA, were used for cDNA synthesis. RNA samples that showed only IGBP3 cDNA specific band of $233 \mathrm{bp}$ were used for RTqPCR for p53 gene (Figure 4).

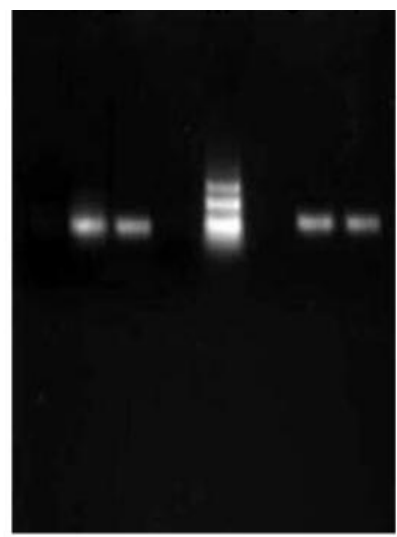

$233 \mathrm{bp}$

\section{Lane M : 1 kbp DNA ladder Lane 1,2,3 \& 4 : p53 cDNA}

Figure 4: PCR amplification of cDNA to check DNA contamination
Amplification curve of different genes are presented in Figure 5. The dissociation curves of various genes have been shown in the Figure 6. There were higher levels of the p53 expressions detected in 9 out of 12 (75\%) cases when compared with normal tissues. Mean p53 expression levels of tumour and normal mammary tissue were 4.7333 \pm 1.4999 and $1.00 \pm .00$ respectively. Comparing the levels of expression of p53 in the canine mammary tumour and the normal mammary tissue, there was a significant increase $(\mathrm{P}<0.05)$ in expression of $\mathrm{p} 53$ in tumour tissue. Relative gene expression level of p53 gene has been shown graphically group wise and individually in Figure 7 and 8 respectively.

Higher level of Cox-2 expressions was detected in 10 out of $12(83.33 \%)$ cases when compared with normal tissues. Mean Cox- 2 expression levels of tumour and normal mammary tissue were $6.93 \pm 2.71$ and $1.00 \pm .00$ respectively. Comparing the levels of expression of Cox-2 in the canine mammary tumour and the normal mammary tissue, there was a significant increase $(\mathrm{P}<0.05)$ in expression of Cox-2 in tumour tissue. Relative gene expression level of

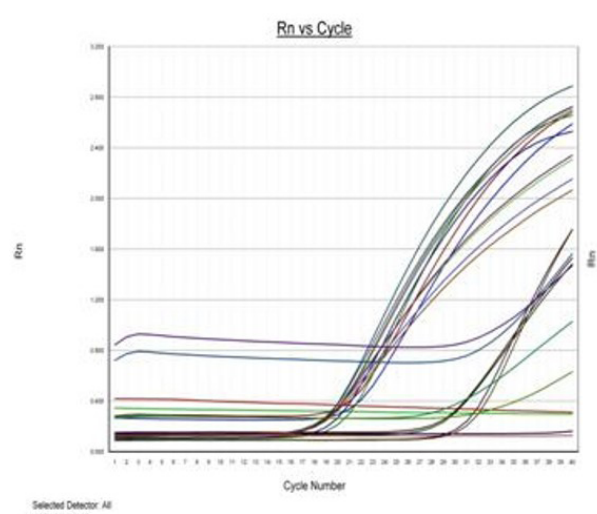

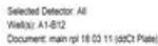

RPL Gene

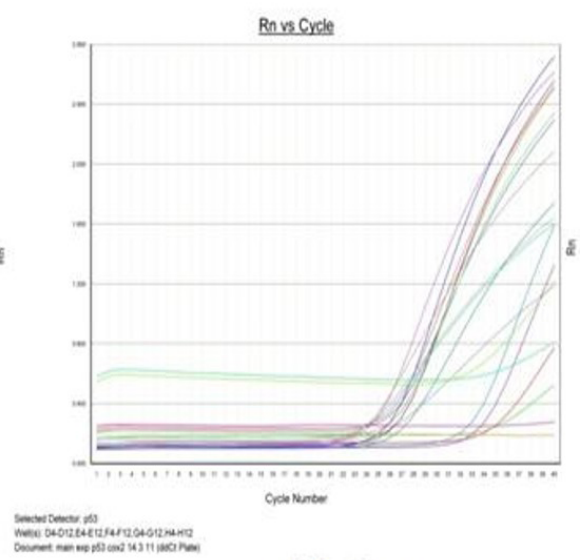

p53 Gene

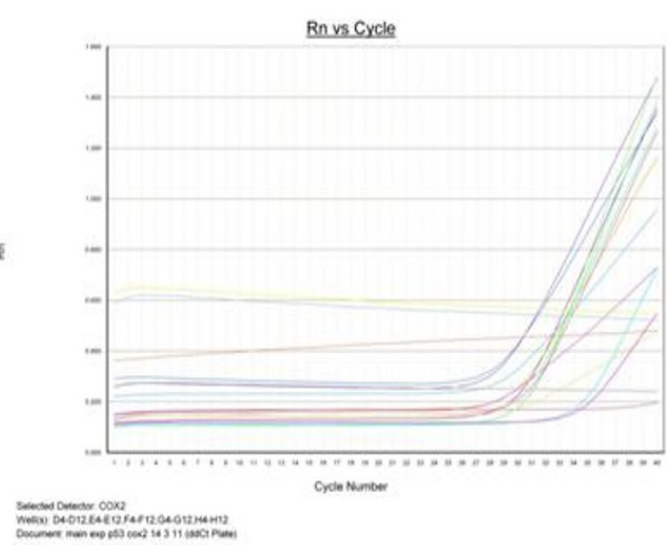

Cox-2 Gene

Figure 5: Amplification curve of different genes in RT-qPCR

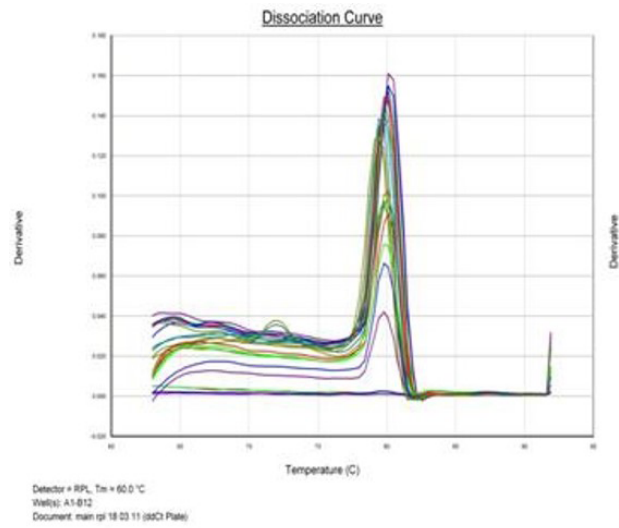

RPL Gene

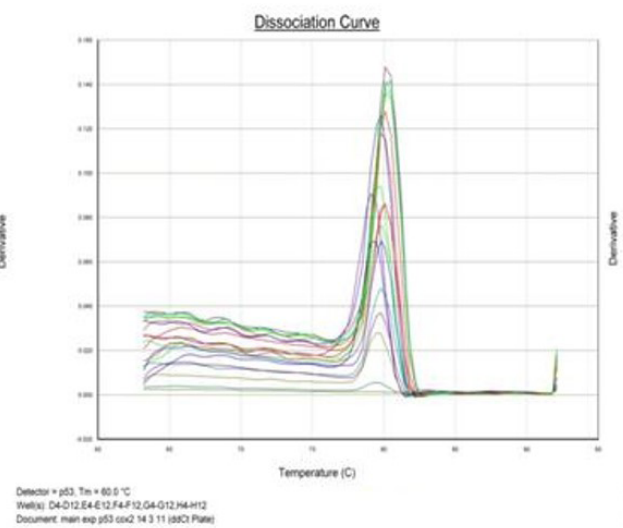

p53 Gene

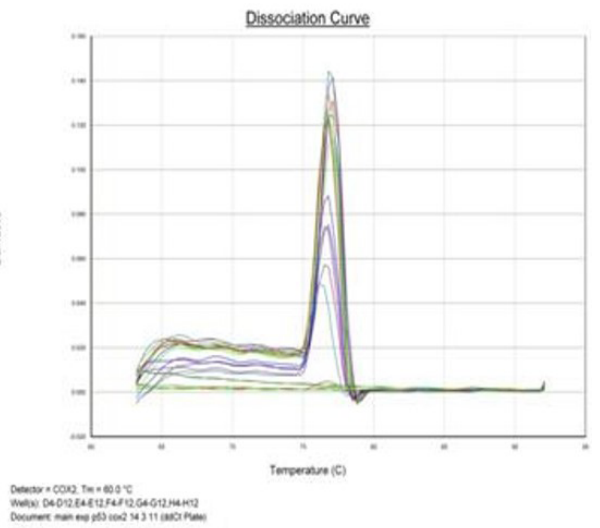

Cox-2 Gene

Figure 6: Dissociation curve of different genes in RT-qPCR 
Cox-2 gene has been shown graphically group wise and individually in Figure 9 and 10 respectively.

Relative gene expression-P53

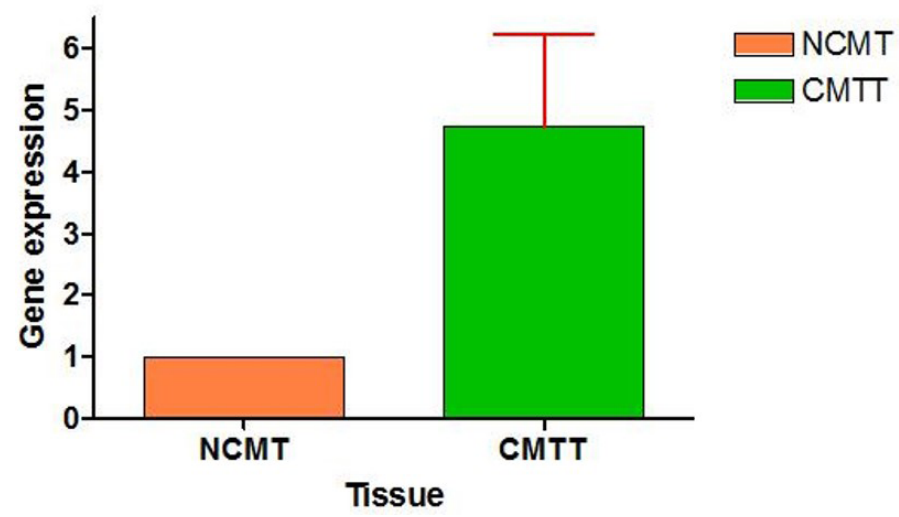

Figure 7: Relative gene expression of p53 gene (Group-wise)

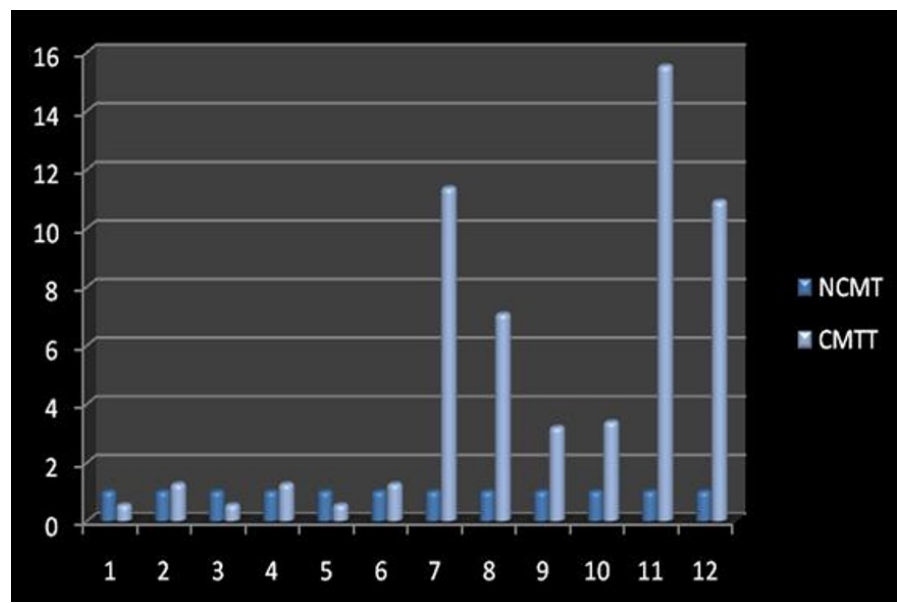

Figure 8: Relative gene expression of p53 gene (Individually) (NCMT-Normal canine mammary tissue; CMTT-canine mammary tumour tissue)

\section{Relative gene expression-Cox2}

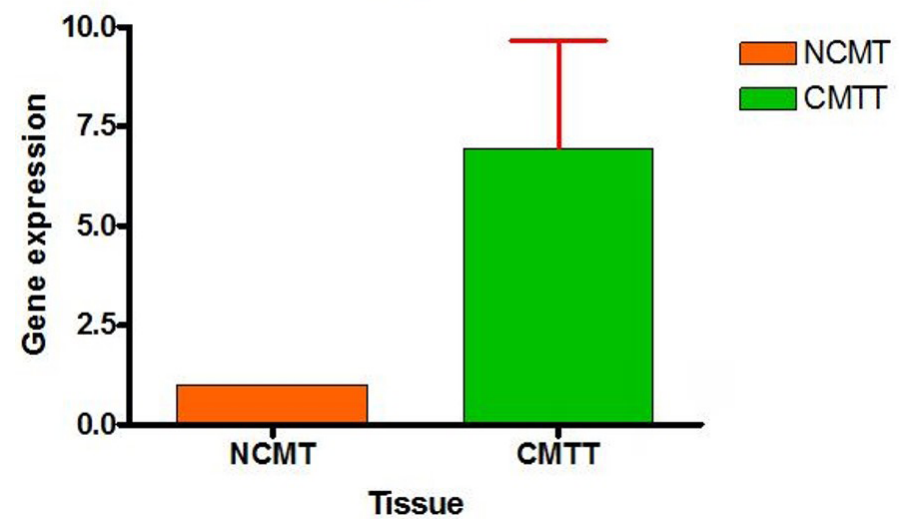

Figure 9: Relative gene expression of Cox-2 gene, (Group-wise)

\section{DISCUSSION}

Mammary neoplasms are the second most frequently encountered neoplasm in female dogs after skin tumour (Divya et al., 2015). Several efforts have been made to- wards the evaluation of prognostic factors including oncogene or tumour markers expression.

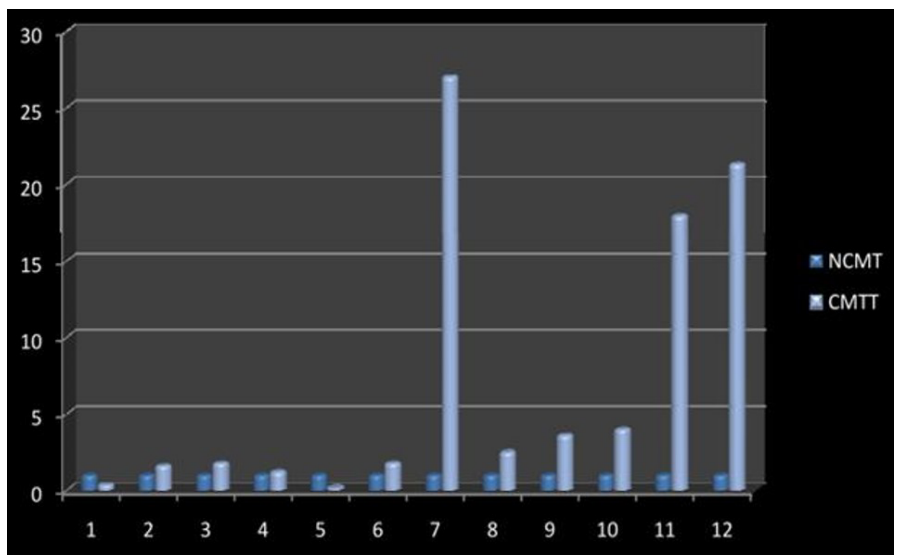

Figure 10: Relative gene expression of Cox-2 gene (Individually) (NCMT-Normal canine mammary tissue; CMTT-canine mammary tumour tissue)

Tumour markers may reflect the neoplastic process by a high/low level of expression relative to that of normal cells, offering a putative use in diagnosis of cancer. They can be measured quantitatively or qualitatively by chemical, immunological or molecular methods. Measurement of tumour markers levels, when used along with other diagnostic tests, can be useful in the detection and diagnosis of some type of cancers (Kumar and Pawaiya, 2010).

In this study, p53 expression was observed in $66.67 \%$ of the mammary tumours as compared to normal tissue where expression was $33.33 \%$. The results showed a high incidence of $\mathrm{p} 53$ overexpression in the canine mammary tumour and particularly this expression was more in malignant tumours than benign. The presence of a p53 mutation is significantly associated with larger tumour diameter (Faille et al., 1994). The p53 mutation used as a risk factor for increased risk of recurrence and death from breast cancer independent of tumour size, hormone receptor levels (Iacopetta et al., 1998). The results of the present study are in agreement with other researcher (Rungzipipat et al., 1999), who also observed p53 overexpression in different canine tumours. Determination of the p53 status in canine cancer patients helped in investigating the role of p53 in mammary tumour formation and its progression (Veldhoen et al., 1999). The p53 gene is an independent factor whose overexpression indicates worst prognosis in canine mammary tumours. In agreement with this study, overexpression of $\mathrm{p} 53$ gene was the useful predictors of increased malignant potential or malignancy of mammary tumours in female dogs (Lee et al., 2004; Ilhan et al., 2008).

In this study, high levels of Cox- 2 expression were detected in $83.33 \%$ of the mammary tumours, where as in normal tissue, expression was $16.66 \%$. The results showed a high incidence of Cox-2 overexpression in canine mammary 
tumour and a trend to be associated with the advanced stages. Cox-2 overexpression was also reported in human and canine mammary tumour (Prescott and Fitzpatrick, 2002; Mohammad et al., 2004). Cox-2 expression is more frequent and more intense in malignant than in benign tumours (Dore et al., 2003). In canine mammary carcinomas, Cox-2 overexpression is directly associated with a high tumour histological grade, greater tumour metastatic and recurrence rates, and reduced survival time. Higher expression of this gene was related to the poor prognosis (Heller et al., 2005; Milanta et al., 2006). The result of the present study was in agreement with other workers who found that about $83 \%$ metastatic lesions of canine mammary gland neoplasia having Cox-2 expression and about 58\% exhibit strong Cox-2 expression (Ilhan et al., 2008). For the treatment and control of advanced neoplastic mammary disease in female dogs, Cox-2 inhibitors could be an alternative (Lavalle et al., 2009).

\section{ACKNOWLEDGEMENTS}

The authors are highly thankful to the Director of the Institute, Head, Surgery Division and Incharge, Veterinary Referral Polyclinics for providing necessary facilities to carry out this study.

\section{CONFLICT OF INTERESTS}

The authors declare that there is no conflict of interests regarding the publication of this paper.

\section{AUTHORS' CONTRIBUTION}

All authors contributed equally.

\section{REFERENCES}

-Brunelle M, Sartin EA, Wolfe LG, Dore M (2006). Cyclooxygenase-2 expression in normal and neoplastic canine mammary cell lines. Vet. Pathol. 43: 656-666. http:// dx.doi.org/10.1354/vp.43-5-656

-Dileepkumar KM, Maiti SK, Kumar N, Zama MMS (2015). Therapeutic evaluation of anti-angiogenic and chemotherapy with or without cox-2 inhibitor and immunomodulator drug in the management of canine mammary neoplasm. Pak. Vet. J. 35: 365-370.

-Divya M, Maiti SK, Sangeetha P, Remya V, Kumar N, Bhatia N (2015). Canine mammary tumours: an hospital based epidemiological study. Indian J. Vet. Med. 35: 159-162.

-Dore M, Lanthier I, Sirois J (2003). Cyclooxygenase-2 Expression in Canine Mammary Tumours. Vet. Pathol. 40: 207-212. http://dx.doi.org/10.1354/vp.40-2-207

- Faille A, Cremoux P De, Extra JM, Linares G, Espie M, Bourstyn E, De Rocquancourt A, Giacchetti S, Marty M, Calvo F (1994). p53 mutations and overexpression in locally advanced breast cancers. Br. J. Cancer. 69: 1145-1150. http:// dx.doi.org/10.1038/bjc.1994.225
Advances in Animal and Veterinary Sciences

- Heller DA, Clifford CA, Goldschmidt MH, Holt DE, Shofer FS, Smith A, Sorenmo KU (2005). Cyclooxygenase-2 Expression is Associated with Histologic Tumour Type in Canine Mammary Carcinoma. Vet. Pathol. 42: 776-780. http://dx.doi.org/10.1354/vp.42-6-776

- Iacopetta B, Grieu F, Powell B, Soong R, McCaul K, Seshadri R (1998). Analysis of p53 gene mutation by polymerase chain reaction-single strand conformation polymorphism provides independent prognostic information in node-negative breast cancer. Clin. Cancer Res. 4: 1597-602.

-Ilhan F, Metin N, Birincioglu ST (2008). Immunohistochemical detection of PCNA and p53 in mammary tumours and normal tissues in dogs. Revue Med. Vet. 159: 298-304.

-Khimta S, Maiti SK, Kumar N, Sharma AK (2010). Occurrence of neoplasms in canine-a retrospective study. Indian J. Anim. Sci. 80: 7-11.

- Kumar P, Pawaiya RVS (2010). Advances in Cancer Diagnostics. Braz. J. Vet. Pathol. 3: 142-153.

-Lavalle GE, Bertagnolli AC, Tavares WLF, Cassali GD (2009). Cox-2 Expression in Canine Mammary Carcinomas: Correlation with Angiogenesis and Overall Survival. Vet. Pathol. 46: 1275-1280. http://dx.doi.org/10.1354/vp.08VP-0226-C-FL

-Lee CH, Kim WH, Lim JH, Kang MS, Kim DY, Kweon OK (2004). Mutation and overexpression of p53 as a prognostic factor in canine mammary tumours. J. Vet. Sci. 5: 63-69. http://dx.doi.org/10.1292/jvms.66.63

- Linjawi A, Kontogiannea M, Halwani F, Edwardes M, Meterissian S (2004). Prognostic significance of p53, bcl-2, and Bax expression in early breast cancer. J. Am. Coll. Surg. 198: 83-90. http://dx.doi.org/10.1016/j. jamcollsurg.2003.08.008

-Livak KJ, Schmittgen TD (2011). Analysis of relative gene expression data using real-time quantitative PCR and the $2-\Delta \Delta$ Ct method. Methods. 25: 402-408. http://dx.doi. org/10.1006/meth.2001.1262

-Maiti SK (2006). Canine mammary cancer- A Review.J. Canine Dev. Res. 4: 65-74.

- Maiti SK, Khimta S, Bhadane B, Kumar N, Sharma AK (2009). Therapeutic evaluation of herbal "ImmuPlus" with or without Doxorubicin in the management of canine mammary tumours. J. Appl. Anim. Res. 36: 103-108. http:// dx.doi.org/10.1080/09712119.2009.9707041

- Maiti SK, Manikandan N, Shivakumar MU, Kumar N, Saikumar G, Gupta OP (2011). Therapeutic evaluation of methotrexate with or without Cox-2 inhibitors in the management of canine mammary tumours. Indian J. Canine Pract. 3: 117-126.

-Milanta F, Citi S, Della-Santa D, Porciani M, Poli A (2006). Cox-2 expression in canine and feline invasive mammary carcinomas: Correlation with clinicopathological features and prognostic molecular markers. Breast Cancer Res. Treat. 98: 115-120. http://dx.doi.org/10.1007/s10549-0059138-z

-Misdrop W, Else RW, Hellmen E, Lipscomb E (1999). Definitions and explanatory notes. Who Histological Classification of Mammary Tumours of the Dog and Cat. Washington: Armed Forces Inst. Pathol. Pp. 18-27

-Mohammad SI, Khan KNM, Sellers RS, Hayek MG, De Nicolo DB, Wu L, Bonney PL, Knapp DW (2004). Expression of cyclooxygenase -1 and -2 in naturally occurring canine cancer. Prostaglandins Leukot Essent Fatty Acids. 70: 479483. http://dx.doi.org/10.1016/j.plefa.2003.10.002 
- Owen LN (1980). The TNM Classification of Tumours in Domestic Animals. Ist ed, Geneva, World Health Organization.

-Prescott SM, Fitzpatrick FA (2002). Cyclooxygenase-2 and carcinogenesis. Biochem. Biophys. Acta. 470: 79-88.

-Queiroga FL, Alves A, Pires I, Lopes C (2007). Expression of Cox-1 and Cox-2 in Canine Mammary Tumours. J. Comp. Pathol. 136: 177-185. http://dx.doi.org/10.1016/j. jсpa.2007.01.010

- Rungzipipat A, Tateyama S, Yamaguchi R, Uchida K, Miyoshi $\mathrm{N}$, Hayashi T (1999). Immuno-histochemical analysis of c-yes and c-erbB-2 oncogene products and p53 tumour suppressor protein in canine mammary tumours. J. Vet. Med. Sci. 61: 27-32. http://dx.doi.org/10.1292/jvms.61.27

-Soslow RA, Dannenberg AJ, Rush D, Woerner BM, Khan KN, Masferrer J, Koki AT (2000). Cox-2 is expressed in human pulmonary, colonic, and mammary tumours. Cancer. 89: 2637-2645. http://dx.doi.org/10.1002/10970142(20001215)89:12<2637::AID-CNCR17>3.0.CO;2-B

-Veldhoen N, Watterson J, Brash M, Milner J (1999). Identification of tumour associated and germ line p53 mutations in canine mammary cancer. Br. J. Cancer. 81:409415. http://dx.doi.org/10.1038/sj.bjc.6690709 